Studies in African Linguistics

Volume 38, number 2, 2009

\title{
THE CURIOUS CASE OF AUXILIARY -MANY'A IN LWITAXO
}

\author{
Robert Botne \\ Indiana University
}

Lwitaxo, one of the Luhya languages of Kenya, has an auxiliary verb of the form -many'a that occurs in compound constructions that express either a generic reading ("normally do V") or a culminative reading ("ended up Ving”). This verb is identical in form to the lexical verb -many'a '(come to) know'. However, while there are attested cases of KNOW verbs grammaticalizing as habitual/generic auxiliaries, there are no such attestations of KNOW verbs grammaticalizing as indicators of culmination. The author proposes that auxiliary -many'a is the unique result of a convergence of factors-sound change, morphophonological analogy, and semantic reinterpretation - that led an original auxiliary, -mala 'finish', to shift in form to resemble lexical -many'a.

\section{Introduction}

In Lwitaxo ${ }^{1}$ (JE.411 [ida $]^{2}$ ), one of the languages of the Luhya macrocluster of southwest Kenya, there occur two complex periphrastic auxiliary verb constructions, both incorporating the auxiliary verb -many'a. One construction has the form SP-many'- $a$ SP-BASE- $a^{3}$ with a GENERIC reading, "normally/ ordinarily/typically V", as in (1). The second has the form SP-Tmany'- $a$ ni-SP-BASE- $a$ and has a CULMINATIVE reading, often suggesting a consequence: "end up Ving", "ultimately V", or "in the end", as in (2).

\footnotetext{
1 There are alternative forms for the name of this language: Lwitaxo, Lwidakho, Itakho, Idakho. Here I have adopted that which is closest to the phonetic representation, including the class prefix. I wish to thank Phoebe Wakhungu for her assistance in providing, gathering, and interpreting data. Tone is marked where possible; some examples are from unrecorded texts. Tone occasionally differentiates lexical items some verbal forms. However, it does not appear to play any role in functions related to auxiliary -many'a.

${ }^{2}$ For lesser known languages, the three letter Ethnologue (www.ethnologue.com) code is provided in brackets.

${ }^{3}$ See the list of abbreviations at the end of the article

${ }^{4}$ Interestingly, in neither case did the consultant think of -many' $a$ as 'know' or derived from 'know', hence the basis for glossing them as -MANY'- and not 'know'.
} 
(1) a. Mu-saxulu na ba-ana ba-anje ba-many'-a ba-xony'-axu-ny'ol-a 1-husband and 2-children 2-1S.POSS 2-MANY'-F 2-help-F 15-find-F

tsin-gutsa.

10 -vegetables

'My husband and children normally help get vegetables.'

b. Ba-shiele ba-ny'ishi ba-many'-a ba-bu-luk-a

2-old_woman 2-many 2-MANY'-F 2-14-make_porridge-F

bu-shuma noho ba-teex-a ma-remwa, ma-pwoni noho

14-type_of_porridge or 2-cook-F 6-bananas 6-sweet_potatos or

tsin-duma xu-lya mubasu

10-yams INF-eat afternoon

'Many women ordinarily make bushuma, or cook bananas, sweet potatoes, or yams to eat in the afternoon.'

c. Tsí-ng'ó:mbé tsi-many'-á tsi-tsy-á mu-mu-chélá xú-ng'wá 'mâ-:tsi. 10-cattle 10-MANY'-F 10-go-F 18-3-river INF-drink 6-water 'Cattle typically go to the river to drink.'

(2) a. I-sí:mba i-many'-i $n$-í-xuts-a. 9-lion 9-MANY'-REC FOC-i-die-F

'Lion ended up dying.' [recent past]

b. Xu-rúla lwénolǒ ba-a-mány'-a ni-bá-'cháák-a xu-húlila 15-come_from then 2-PST-MANY'-F FOC-2-begin-F 15-feel

bu-tsuni, bu-lwále, xali xu-xútsa. [Good News program (GNp)] 14-pain 14-sickness also 15-die

'From that time, consequently they began to feel pain, sickness, and also death.' 

c. Ly-a-many'-a ni-li-chimil-a
mu-shiele
oyo ni-li-eny'-a
5-RM-MANY'-F FOC-5-grasp \& hold-F 1-old_woman 1.that PRT-5-want-F
xu-mu-lya.
15-1-eat

'It [ogre] ultimately got hold of that old woman, wanting to eat her.'

The culminative constructions in (2) differ from the generic constructions in (1) in that they always (seem to) require the focus marker $n i-.^{5}$ All fifteen of the culminative examples in the data occur with $n i$-, while none of the six generic examples do. This is not surprising as the culminative use focuses on the event as the culmination of a series of events, while the generic does not refer to any specific event. This distinction is crucial, ultimately, for the difference in analysis of the two homophonic auxiliaries.

What is curious about this case is not the constructions per se, but rather the form and use of the auxiliary verb itself. It has the same form as the verb '(come to) know' -many'a, yet there appear to be no cases attested in the literature of KNOW verbs grammaticalizing in other languages with a sense of culmination 'consequently, ultimately, in the end' noted here. Significantly, however, Appleby (1943) notes a comparable auxiliary verb construction for central Luhya languages having the same culminative sense found above for Lwitaxo, but incoporating instead the auxiliary -mala 'finish'. The verb -mala 'finish' is found in Lwitaxo as well, but it expresses a completive function, not the culminative function noted for this particular auxiliary verb construction. Intriguingly, a cognate form of -mala (from Proto-Bantu *-mad- (Bastin et al. 2003))_-*-màn- 'finish' - is attested in western Bantu zones, but there are no reflexes of it attested in either zones E or J where Lwitaxo is located. So, does this -many'a case represent a new and unique grammatical evolution of KNOW, an extension to the range of *-màn-, or something else?

There is no published linguistic literature specifically on Lwitaxo. There do exist a grammar and a dictionary of Luhya by Appleby (1961, 1943, respectively) that may have been based in part on Lwitaxo data. Data for this study come primarily from Phoebe Wakhungu, a native speaker from Kakamega district, through direct elicitation and both recorded and written texts,

\footnotetext{
${ }^{5}$ I thank Tucker Childs and an anonymous reviewer for pointing out this distribution. There are five different functions associated with the form $n i$-: copula (COP), participial (PRT), sequentive (SEQ) (often equivalent to 'and' or 'then'), temporal 'when', and focus (FOC). Focus is the only one that occurs as a prefix on the second (complement) verb in complex periphrastic constructions, such as the generic and culminative cases with -many'a.
} 
supplemented by texts from other sources (e-mail messages, facebook messages, the Good News Program). There is no standard orthography for Lwitaxo, although there has been an attempt to standardize an orthography for Luhya as a whole. ${ }^{6}$

\section{Auxiliary verbs in Lwitaxo}

Auxiliary -many'a is one of seven verbs that play an auxiliary role in Lwitaxo. Each has an aspectualizing function, of which there are three types: event phase aspectualizers (3a), sequencing aspectualizers (3b), and iteration aspectualizers (3c). The general form of the construction each occurs in is listed with each type. A representative exemplar accompanies each type.

(3) Aspectualizing auxiliaries

a. Event phase aspectualizers [SP-T-AUX-F INF-STEM]

-ránga 'start', -anza 'begin', -mala 'finish'

Lwa kw-a-mal-a xu-lya, kw-a-anz-a xu-londa harufu ya when 20-PST-finish-F 15-eat 20-PST-begin-F 15-follow 9.smell 9.LNK

ba-ana.

2-children

'When it [ogre] finished eating [the houses], it began to follow the smell of the children.'

b. Sequencing aspectualizers [SP-T-AUX-F (ni-)SP-BASE-F] -ránga 'first(ly)', -many'a 'ultimately, in the end'

Ni-y-axa-rul-a xu-kaasi, a-rang-a a-hulux-a when-3S-PF-come_from-F LOC-work, 3S-do_first-F 3S-rest-F

n-a-shi-li $\quad$ xu-teexa

when-3S-still-be INF-cook

'When she has come [home] from work, she first rests before cooking.'

\footnotetext{
${ }^{6}$ The digraph $n y$ ' has been used to represent phonetic [n]. This is comparable to $n g$ ' used to represent phonetic [n].
} 
c. Iteration aspectualizers [SP-T-AUX-F (ni)-SP-BASE-F]

-meny'a 'repeatedly', -many'a 'normally'

A-mény'-i n-á:-ts-a i-Musíngu.

3S-ITER-PFV FOC-3S-go-F 23-M.

'He repeatedly went to Musingu.' [yesterday/today]

The sources of these verbs, other than -many'a, are transparent for the most part. The verb -ránga 'do first; start' derives from Proto-Bantu *-táng- 'go ahead (of)', -anza 'begin' from PB *-jandi- 'begin' (Bastin et al. 2003), -mény'a 'repeatedly' from -mény'a 'live', a conceptual shift similar to that found in Gikuyu [kik] and Aztec [nhk] (Heine \& Kuteva 2002:196). We turn now to a consideration of the -many'a cases.

\section{Generic -many'a}

Generic -many'a, as noted in the introduction, expresses the normal, typical nature of the situation named by the verb, as in (4). It occurs as well in physically and genetically closely related Lulogooli (JE41 [rag]), as in (5). Conceptually, it is close to the habitual. Indeed, Bybee et al. (1994:151-52) point out that the distinction between habitual and generic is not particularly clear, that the difference is often determined only by specific versus generic subject. Consequently, and directly related to the case at hand, Bybee et al. (Ibid. 154) show that one source for habitual (and generic, we can presume) auxiliaries is a KNOW verb.

(4) Ba-ndu ba-li nende tsi-shilinji ni-b-o ba-many'-a ba-reeb-a

2-people 2-be with 10-money COP-2-REF 2REL-AUX-F 2-ask-F

ba-ndu ba-li nu bu-hasio ba-ba-lim-il-i mi-limi chi-abo.

2-people 2-be with 14-group 2-2-till-AP-SUBJ 4-fields 4-3S.POSS

'People who have money are the ones who normally ask people who are with a group to till their fields for them.' 
(5) Lulogooli (Bantu JE41 [rag], Kenya)

$$
\begin{array}{ll}
\text { a-many'- } a & \text { a-som-ang- } a \\
\text { 1-MANY'-F } & \text { 1-read-IMPV-F } \\
\text { 'He usually reads.'(Angogo Kanyoro 1983:106) }
\end{array}
$$

Instances of KNOW verbs attested as habitual or generic auxiliaries, according to Bybee et al. (1994:155) and Heine \& Kuteva (2002), can be found in Haitian Creole kôn (from French connaitre 'to know, be acquainted with') and Tok Pisin ([tpi]) savi (from Portuguese save 'he knows'), both of which express habitual uses, present in Tok Pisin, past in Haitian Creole. The Tok Pisin use appears to be a calque from its prominent substrate language, Tolai (also known as Kuanua [ksd]), which uses la 'know' in like manner, as in (6). In contrast, I have found no evidence of such use in Kwa languages, which are considered the primary substrate of Hatian Creole.

(6) Tolai (Western Oceanic [ksd]; Papua New Guinea)

$$
\begin{aligned}
& u \quad \text { la vana } \\
& 2 \text { S know go } \\
& \text { 'You usually go.' (Mosel 1980:124) }
\end{aligned}
$$

Similar cases are found in the Khmer auxiliary ceh-tae 'always, typically' $(<c e h$ 'know (how to)') (7a), and in Mooré (7b), which has the sense 'usually'. Papiamentu $s a$ (from $s a b i$ 'know') exhibits both habitual and generic readings (8).

(7) a. Khmer (Austro-Asiatic, Mon-Khmer [khm]; Cambodia [khm])

koăt ceh-tae niyizy phizsaa-baray

$3^{\text {rd }}$ AUX speak language-French

'He/she/they always/typically speak/s French.' (Huffman 1970:269)

b. Mooré (Niger-Congo, Gur [mos]; Burkina Faso)

a mi $n$ loda $k a$

3S know ?? pass here

'he usually passes here' (Alexandre 1953:251, cited in Heine et al. 1993:132) 
(8) Papiamentu (Creole [pap]; Netherlands Antilles)

a. Habitual

E ora ei, el a kambia rumbo trot purá-purá bai subi

This moment then he PFV change direction trot rapidly go climb

sinta denun mata grandi ku tabatin pegákuboka di e pos

sit in a tree large that IMPV near mouth of the well

kaminda su kasá tabata sa bai saka awa tur dia.

where his wife IMPV AUX go draw water every day

'A that moment, he took another direction, trotting rapidly to sit above a large tree near the well where his wife went to draw water every day.' (Henriquez 1981:15, cited in Maurer 1988:122)

b. Generic

no a tend nunka ku makaku no sa kana ku kurason NEG PFV hear never that monkey NEG AUX walk with heart

denkurpa?

In body

'Have you never heard tell that normally monkeys do not walk about with their heart in their body?' (Kleinmodig n.d.:54, cited in Maurer 1988:123)

In its generic reading, then, we can propose that auxiliary -many' $a$ has developed from lexical -many'a '(come to) know'. As a lexical verb, -many'a has followed a common path of generalization of meaning from mental ability (9a) to physical ability (9c). In all cases, it expresses a state. Although Bybee et al. suggest that it is the general sense of experience that may lead to the habitual use, it seems likely that, in the case of the generic, it was also expression of a characteristic mental state ('knowing that') that was extended to expression of characteristic physical behavior ('characteristically does that').

a. níba y-á:-many'-a injila, shichilá shi-a-bul-i xu-mú-mani-iny'-a? if 3S-ST-know-F 9.path 7-reason 7-3S-lack-PFV 15-3S-know-CAUS-F 'if he knows the way, why did he not show you?' 
b. keny'exá mú:ndu muxáli a-many'-é xu-li:nda ba:na should 1.person 1.female 1-know-SUBJ 15-tend 2.children 'a woman should know (how) to care for children'

c. y-á:-many'-axu-tééxa buláyi 3S-ST-know-F INF-cook well 'she knows (how) to cook well'

That -many'a should have grammaticalized in Lwitaxo as a marker of a generic state, then, may be relatively uncommon, but is nevertheless attested in a variety of languages. The semantics of this shift are transparent; the generic state denoted by know in, for example, they know (how) to cook porridge becomes the basis for understanding the narrated activity as typical or normal, as in they normally/typically cook porridge. Assuming, then, -many' $a$ 'know' as the source for -many'a generic auxiliary, we turn to an examination of -many'a in its culminative function.

\section{Culminative -many'a}

In its culminative use, as illustrated by the examples in (10), -many'a denotes some situation as the final stage of some series or sequence of events, translated typically as ultimately, or in the end. This differs from completive use as defined in Bybee et al. (1994:54) as "do[ing] something thoroughly and to completion", such as "eat up" or "shoot someone dead". Thus, completive refers to the final stage of a single event, culminative to the last of a sequence of events.

$$
\begin{array}{lllll}
\text { a. Maama } & \text { w-anje } & y \text {-a-many'a } & \text { ni-y-ibul-a } & b a-n d i \\
\text { 1a.mother } & 1-1 \text { S.POSS } & \text { 1-PST-MANY'-F } & \text { FOC-1-give_birth-F } & \text { 2-other } \\
\text { ba-ana sita xu-londa inzi. } & \\
\text { 2-children six 15-follow } \quad \text { 1S }
\end{array}
$$

'My mother ultimately gave birth to six other children following me.' 
b. Ny'asáye y-a-mány'-a n-á-lomb-á mu-ndú xu-bá mu-rúch-i 1a.God 1-PST-MANY'-F FOC-1-make-F 1-person 15-be 1-rear-AG

wí-tsi-ny'ama tsy-óosi.

1.LNK-10-animal 10-all

'In the end, God made man to be caretaker of all animals.' [GNp]

c. Xulwá $\quad y$-ak-ô:; $\quad y$-a-mány'-a $\quad n$-á-bá-xung-a-mu. based_on DEM-12-DIST 1-PST-MANY'-F FOC-1-2-drive_out-F-18 'Based on that, he ended up driving them out from there.' [GNp]

I have been unable to locate any documented case of a verb grammaticalizing as an auxiliary denoting culmination (e.g., Heine \& Kuteva 2002, Heine et al. 1993). If this is, indeed, the case, then Lwitaxo -many'a 'know' as culminative marker would appear to be a unique case. Yet, the forms clearly match; the semantics also conform. In Lwitaxo, -many'a 'know' is not a pure stative verb, but a change-of-state achievement verb, with a punctual nucleus and stative coda phases. ${ }^{7}$ Consider the differences in interpretation of -many' $a$ with suffixes $-i$ (perfective) and - $i$ (recent past) in the examples in (11). In (11a), the perfective indicates a perspective at utterance time (UT) in the stative coda phase (bold bar), hence, subject $I$ knows the path with no indication of when that knowing came about (i.e., at the punctual nucleus). In (11b), in contrast, the focus is on the change of state, the point (Nucleus) at which cognitive realization occurred at some time in the recent past. In both (12) and (13), it is this point of realization that is denoted.
a. many'- $i$ in-jila
1S.know-PFV 9-path
'I know the way'

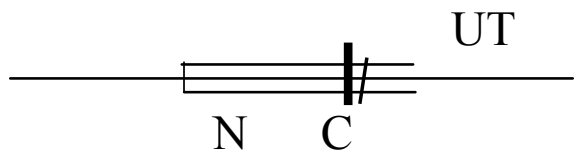

b. many'-i in-jila

1S.know-REC 9-path

'I know the way'

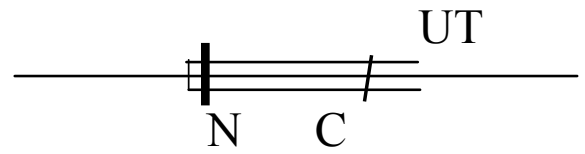

['I recently became cognizant of the way and, hence, know the way']'

\footnotetext{
${ }^{7}$ See Botne (2003) for a detailed discussion of the temporal structure of Achievement verbs. Nucleus denotes the characteristic core phase named by the verb, Coda a post-nucleus phase which, in Achievements, is a state.
} 
(12) Lwá a-mal-í xu-lomaloma many'-i ndía-beh-á tâ:we. when 3S-finish-REC INF-talk 1S.know-REC that 3S-lie-F NEG 'When s/he had finished talking, I realized (knew) that s/he was not lying.'

(13) Akumba y-a-húlil-a li-nání ní-lí-chend-ang-a; ly-a-mány'-a ndí 1a.Akumba 1-RM-hear-F5-ogre PRT-5-walk-IMPV-F 5-RM-know-F that

mú:ndu y-a-li n-a-li hí:mbi xú ly-a-xááb-a mú:ndu mwé:neyó 1.person 1-RM-be ??-1-be 16.near so 5-RM-search-F1.person 1.same.16

wá-y-a-li ní-y-í-bís-i.

16.LNK-1-RM-be FOC-1-RFLX-hide-PFV

'Akumba heard an ogre walking; it [ogre] realized (knew) that someone was nearby, so it searched for where that person had hidden herself.'

As an achievement verb, then, -many'a is equivalent in part both to English realize and know, the former denoting the point of transition, the latter the state. It is not difficult to imagine a semantic shift from mental realize "come to know fully' to physical realize 'bring to realization', the basis for culmination being ultimately, or in the end, realized.

A similar kind of grammaticalized change appears to have occurred in Gikuyu (E51 [kik]) with the achievement verb -kora 'find, discover; realize'. Heine et al. (1993:86) label -kora a "finality marker", illustrated in (14).

(14) Gikuyu (Bantu E51 [kik], Kenya)

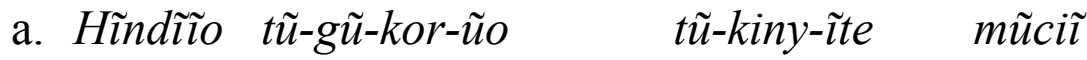
time that 1P-PST-find-PASS 1P-arrive-PFV village 'By then we [were found we] had reached the village.'

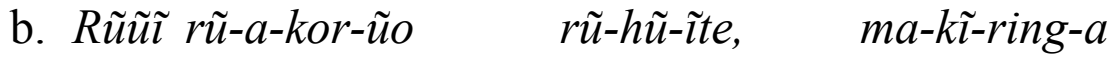
11.river 11-PST-find-PASS 11-subside-PFV 2-then-cross-F 'When the river [was found it] had subsided, [then] they crossed.' (Heine et al. 1991; Barlow 1960)

Nevertheless, though a change from lexical 'know' to grammatical culminative marker is certainly plausible, Lwitaxo appears to be unique in this development. Neighboring central Luhya languages closely related to Lwitaxo, 
according to Appleby (1943), have a very similar complex construction, but with auxiliary -mala 'finish' rather than -many'a, as in (15).

(15) Luhya
a. $y$-a-mal-a n-a-tsy-a 3S-RM-finish-F FOC-3S-go-F
'In the end, he went.'

b. y-a-siny'ikh-a po, ne shi-y-a-mal-a n-a-khol-a eshindu ta 3S-RM-be angry-F very and NEG-3S-RM-finish-FFOC-3S-do-F 7.thing NEG 'He was very angry; and in the end he didn't do anything.' (Appleby 1943:70)

FINISH verbs are often attested as grammaticalizing as auxiliaries or affixes that denote some kind of completion or culmination (Heine et al. 1993; Bybee et al. 1994; Anderson 2006) of a situation, as in Engenni (16), Spanish (17), and Wolio (18).

(16) Engenni (Niger-Congo, Edoid [enn]; Nigeria)
a. bhùsye dhe sise you remove finish put 'You take it right off [the fire] and put it down.'
b. ànị ạlibò dire padhe ạki wifeof.tortoise cook finish pot
'Tortoise's wife finished cooking.' (Thomas 1978:110, 172)

(17) Spanish
acab-ó escrib-iendo la carta finish-3S.PST.IND write-GER DEF letter 'Finally he wrote the letter.' (Halm 1971:160, cited in Heine et al. 1993:90)

(18) Wolio (Austronesian [wlo], Malayo-Polynesian; Indonesia)
a-pade-a a-kande-a
3-finish-e 3-eat-3
'he ate them all up' (Anceaux 1988, cited in Anderson 2006:308) 
Luhya languages are similar in that -mala 'finish' is used in complex constructions to denote completion. Lwitaxo is not unlike other Luhya languages, such as neighboring Luwanga [lwg], in this respect, in that either completion of a situation-(19) for Luwanga, (20) for Lwitaxo-or ultimate affectedness - (21) for Luwanga, (22) for Lwitaxo - can be denoted through use of -mala.

(19) Luwanga -mala as completive (Botne 2010)

a. xo, ly-axa-mal-a oxu-lya, ni-li-sung-a li-ri... so 5-PF-finish-F 15-eat SEQ-5-ask-F 5-QUOT 'So, having finished eating, it [ogre] would ask ...'

b. ómwaayi wayô: y-a:-mal-íré oxu-ula ewa:bu 1.herder 1.LNK.its 1-P2-finish-PFV 15-arrive 24.LNK.their 'Its herder had already arrived at his home.'

(20) Lwitaxo -mala as completive

a. Ni-b-axa-mal-a xu-ng'wa i-chiai, b-ochits-a bi-kombe. when-3P-PF-finish-F INF-drink 9-tea 3P-wash-F 8-cups 'When they have finished drinking [their] tea, they wash out the cups.'

b. Lwa ba-a-mal-a xu-teexa, mu-shiele oyo y-a-bool-el-a ba-ana .. when 2-PST-finish-F 15-cook 1-old_woman 1.this 1-PST-tell-APP-F 2-child 'When they finished cooking, that old woman told her children ...'

(21) Luwanga

Paápa, eshitáli shi-litáari;e-mal-íré oxu-kásya Papa 7.bed 7-be_ready 1S-finish-PFV 15-prepare 'Papa, the bed is ready; I have made [it] all up.' 
(22) Lwitaxo

Ku-nani yoko kw-a-ly-a xali tsin-g'o:mbe, tsim-buli,nende 20-ogre 20.that 20-PST-eat-F even 10-cattle 10-goat and

ma-ko:ndi. Lwa kw-a-mal-a xu-lya kw-a-rang-a xu-kaluxa 6-sheep when 20-PST-finish-F15-eat 20-PST-start-F 15-return

mu-mu-chela

LOC-3-river

'That giant ogre ate even the cattle, goats, and sheep. When it finished eating [up all the livestock], it set off to return into the river.'

Auxiliary -mala is one of three event phase aspectuals in Lwitaxo that typically occur with an infinitival complement, as -mala does in (20) and (22). These verbs profile and highlight specific phases of an event. Two verbs select for initial phases - -ranga 'start' for the onset of the event, -anza 'begin' for the initial phase of the nucleus of the event - one for the final phase-mala 'finish' for the end of the situation nucleus (23).

(23) Situation phase aspectuals in Lwitaxo

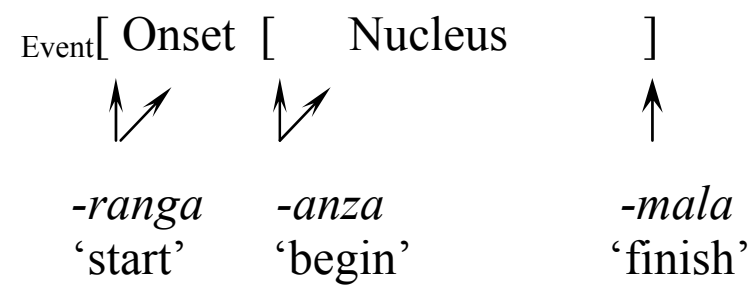

This use of auxiliary -mala as denoting a completed situation is common to both languages; its use to denote culmination of a sequence or series of events is not. In fact, it is this use that is unusual. That Lwitaxo would have -many'a in the same role where neighboring Luhya languages have -mala suggests that they were likely the same originally, but one has subsequently changed. Given the absence of attestation of KNOW grammaticalization as a culminative auxiliary in any language, the likely candidate to have undergone change would appear to be -many'a. 


\section{Culminative -many'a from -mala?}

The fact that neighboring languages have a comparable culminative periphrastic construction based on auxiliary -mala 'finish', a verb commonly grammaticalizating with some kind of completive/culminative function, and that -many'a '(come to) know' is unattested with this function, suggests that -mala was, in fact, the source of the culminative auxiliary in Lwitaxo, the extant nature of -mala notwithstanding. The question is, how would the auxiliary come to have the same form as the lexical verb -many' $a$ ?

Interestingly, one widespread reflex of $\mathrm{PB} *$-mad- 'finish' is -mana, in which we find a nasal in place of the oral stop. However, there is no evidence to support an analysis of auxiliary -many'a as a cognate reflex of *-mana, which is found exclusively in the western zones of the Bantu domain (i.e. zones A, B, C H, K, L M, R), not in the eastern (Bastin et al. 2003) (see map in Appendix 3). Moreover, there is no evidence to support its ever having occurred in the eastern zone. Nevertheless, there is some circumstantial support for a possible change from [1] to [n] in Lwitaxo. The causative suffix -its- is realized as -iny'following a preceding nasal consonant, hence, -lema 'become lame' > -lem-iny'$a$ 'make lame' (cf. -yanz-a 'like' > -yanz-its-a 'please'). This alternation, the only one involving nasal harmony in Lwitaxo (apart from assimilation in NC clusters), is unknown for causatives in Bantu in general. Be that as it may, the correspondence between coronal consonant and palatal nasal does exist in the language.

Second, we find that aspectualizing auxiliary verbs typically have a rootfinal nasal consonant or cluster: -rang- $a$ 'be first', -anz- $a$ 'begin', -meny'- $a$ 'repeatedly', many'-a 'normally'. Auxiliaries -many'a 'normally' and -meny'a 'repeatedly' (derived from lexical -meny'a 'live') are particularly relevant because they, too, are grammaticalized verbs having forms like or very similar to -many'a. Significantly, -meny'a also occurs as an auxiliary of repeated or continual action in other Luhya languages - both in Lusaamia (see Botne 2008) and Luwanga (Botne field notes) - suggesting that it preceded the occurrence of -many'a in Lwitaxo.

Both auxiliary -meny' $a$ and -many' $a$ occur in a construction in which the $[\mathrm{n}]$ is situated between two nasal consonants:

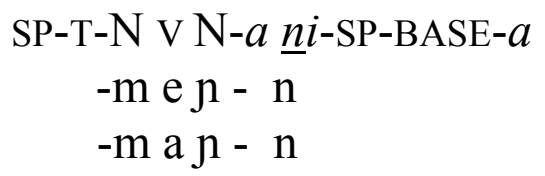


Assuming -many'- was originally -mal-, there may have been pressure to nasalize the [1] of -mal- to conform to a perceived general pattern of nasalization as -mala grammaticalized in this syntactic context. We would expect, then, to find -mana, which in fact does not occur. I propose that, in this instance, the [1] nasalized, but was realized as [n] rather than as [n], for three reasons: (1) phonologically, like coronal [ts] of the causative, coronal [1] was replaced with a palatal nasal; (2) phonologically, by analogy with the palatal nasals in -meny'a and -many' $a$ whose forms and functions are very similar to the auxiliary use of -mala; and (3) semantically, the achievement verb -many'a 'come to know' was an appropriate fit for the culminative sense. This analysis, then, suggests a chain of development something like that illustrated in (24), in which phonological and semantic factors converged to change -mala to -many' $a$, making auxiliary -many'a appear to be a grammaticalization of -many'a 'come to know'.

(24) Stages in the development of auxiliary -many'a 'ultimately, in the end'

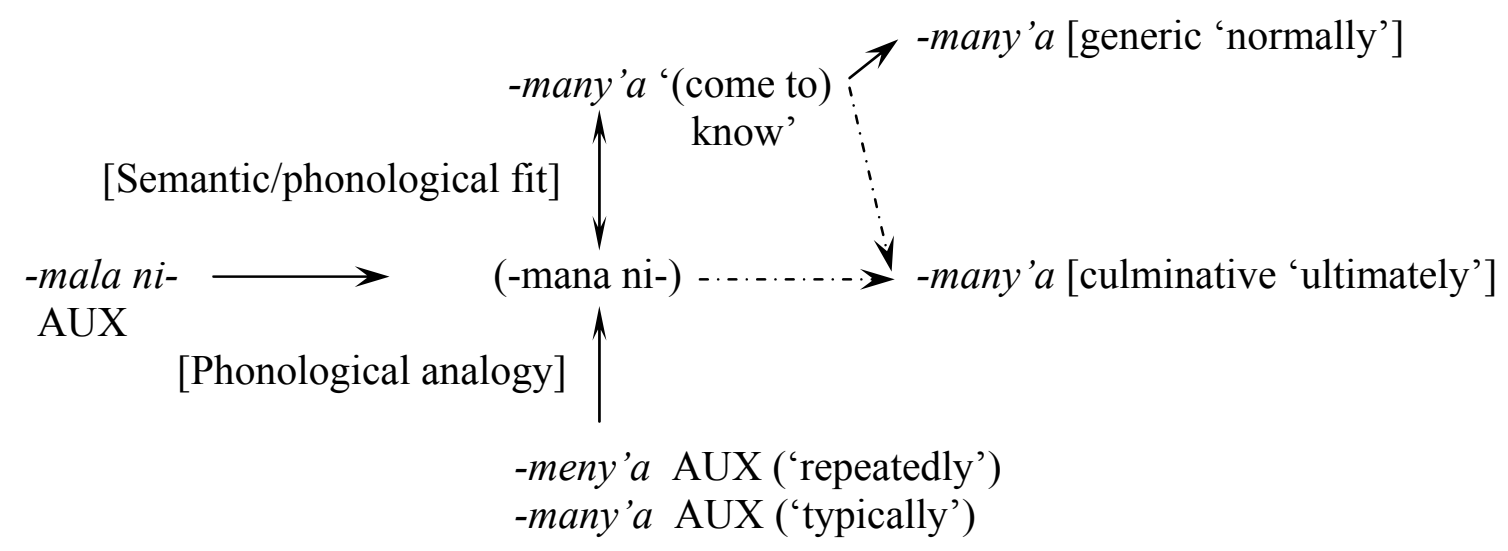

Auxiliary -mala used as a completive marker of a [simple] situation did not shift in form, as it occurred in a different phonological and syntactic environment: there was no nasal following the verb, since the complement of -mala 'finish' was the infinitival form in $x u$-: SP-T-NVC- $a x u$-STEM. 


\section{Conclusion}

The curious occurrence of -many'a, an apparent verb of knowing, as an auxiliary of culmination in Lwitaxo has been attributed here to a convergence of phonological, analogical, and semantic factors that conspired to shift an original auxiliary verb form -mala (lexically 'finish') to a form that resembles the lexical verb -many'a. That the original form was not -many'a seems highly likely for three reasons. First, there appear to be no other languages that have grammaticalized a KNOW verb as culminative marker. Second, FINISH verbs such as -mala have been attested to grammaticalize with completion and/or culmination. Third, just such an auxiliary construction occurs in neighboring languages with the verb -mala 'know', Lwitaxo standing out by its difference. Consequently, we conclude that -mala was the original source, change triggered by a nasalizing environment, with -many' $a$ the ultimate realization. Thus, it may be the process, itself, rather than the source, that is rare or unique.

\section{Abbreviations used:}

\begin{tabular}{|l|l|l|l|l|l|}
\hline AG & agentive suffix & IND & indicative & RFLX & reflexive \\
\hline AUX & auxiliary & INF & infinitival prefix & REC & recent past \\
\hline CAUS & causative & LNK & linking element & RM & remote past \\
\hline DEF & definite article & LOC & locative clitic & SP & $\begin{array}{l}\text { subject agreement } \\
\text { prefix }\end{array}$ \\
\hline DEM & demonstrative & NEG & negative & ST & stative present \\
\hline DIST & distal & PF & perfect & SUBJ & subjunctive \\
\hline F & final vowel & PFV & perfective & T & tense marker \\
\hline GER & gerundive & PRT & participial & 1S & first person singular \\
\hline IMPV & imperfective & PST & past & 3S & third person singular \\
\hline
\end{tabular}




\section{References}

Alexandre, Gustave. 1953. La langue Moré. Tome II: Dictionnaire moré français. Dakar:IFAN.

Anceaux, J. C. [1952] 1988. The Wolio Language: Outline of Grammatical Description and Texts $\left(2^{\text {nd }}\right)$. Dordrecht: Foris.

Angogo Kanyoro, Rachel. 1983. Unity in Diversity: A linguistic survey of the Abaluhyia of Western Kenya. Vienna: Institute für Afrikanistik und Ägyptologie der Universität Wien.

Anderson, Gregory D. S. 2006. Auxiliary Verb Constructions. Oxford and New York: Oxford University Press.

Appleby, L. L. 1943. A Luluhya-English Vocabulary. Maseno, Kenya: C.M.S.

Appleby, L. L. 1961. A First Luyia Grammar. Nairobi: East African Literature Bureau.

Bastin, Yvonne, André Coupez, Evariste Mumba, and Thilo C. Schadeberg. 2003. Bantu Lexical Reconstructions 3. [Online: www.metafro.be/blr]

Botne, Robert. 2010. Perfectives and perfects and pasts, Oh my!: On the semantics of -ile in Bantu. African Linguistica. XVI: 31-64

Botne, Robert. 2003. To die across languages: Toward a typology of achievement verbs. Linguistic Typology 7,2: 233-278.

Bybee, Joan, Revere Perkins, and William Pagliuca. 1994. The Evolution of Grammar. Chicago and London: The University of Chicago Press.

Good News program (C18971). www.ind.globalrecordings.net/program/c18971.

Halm, W. 1971. Moderne spanische Kurzgrammatik. München: Max Weber Verlag. 
Heine, Bernd, Tom Güldemann, Christa Kilian-Hatz, Donald A. Lessau, Heinz Roberg, Mathias Schladt, and Thomas Stolz. 1993. Conceptual Shift: A lexicon of grammatical processes in African languages. Afrikanistische Arbeitspapiere 34/35.

Heine, Bernd and Tania Kuteva. 2002. World Lexicon of Grammaticalization. Cambridge: Cambridge University Press.

Huffman, Franklin E. 1970. Modern Spoken Cambodian. New Haven and London: Yale University Press.

Maurer, Philippe. 1988. Les modifications temporelles et modales du verbe dans le Papiamento de Curaçao (Antilles Néerlandaises). Hamburg: Helmu Buske Verlag.

Mosel, Ulrike. 1980. Tolai and Tok Pisin: The influence of the substratum on the development of New Guinea Pidgin. Pacific Linguistics No. 73, Series B. Canberra: The Australian National University.

Thomas, Elaine. 1978. A Grammatical Description of the Engenni Language. Dallas: SIL and the University of Texas, Arlington.

Robert Botne Indiana University

Department of Linguistics Memorial Hall 322

Bloomington, IN 47405

botner@indiana.edu
Received: June 4, 2010

Accepted: August 21, 2010 
Appendix 1: Map of the Luluhya macrocluster of languages [adapted from Angogo Kanyoro 1983]

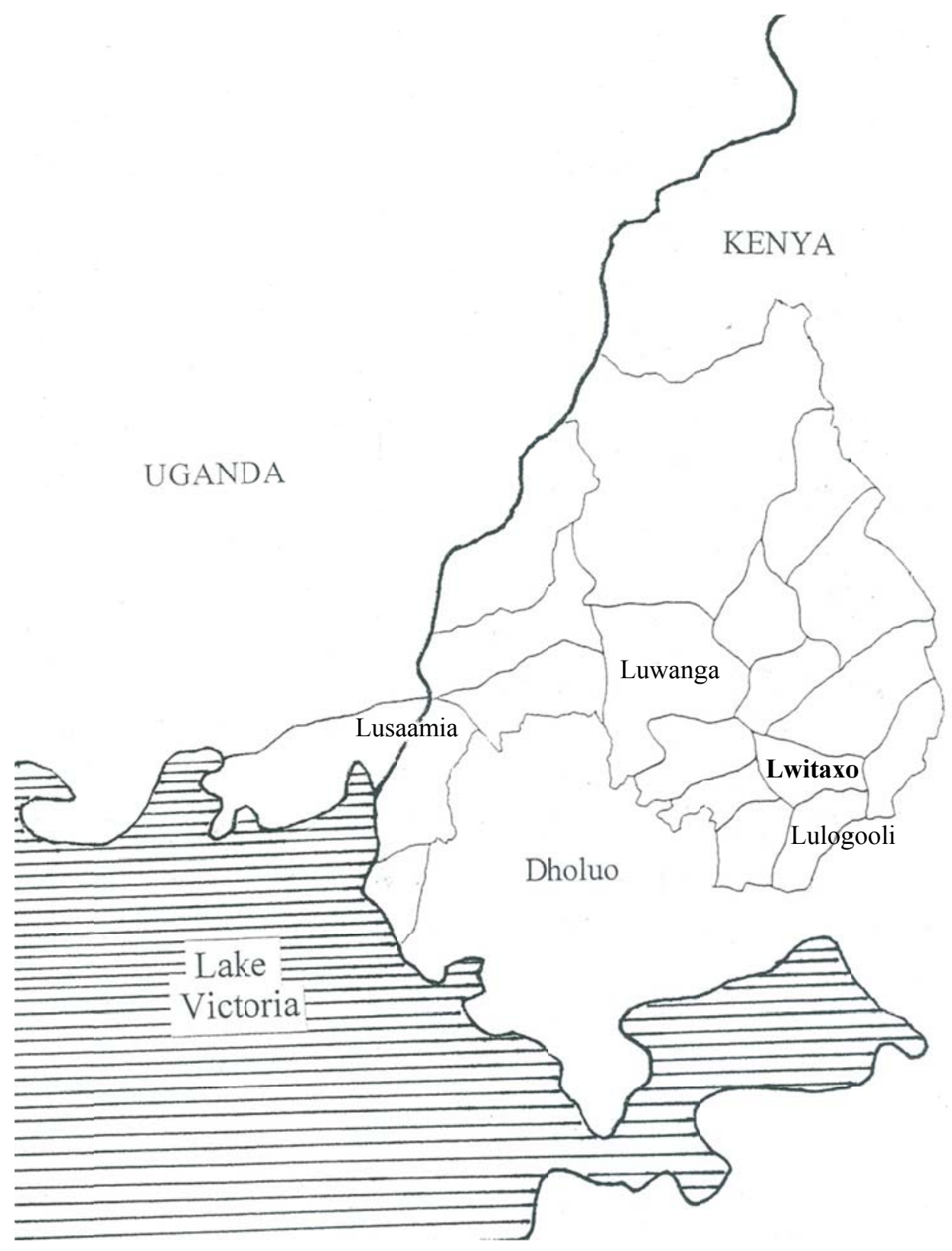


Appendix 2: Map of Bantu zones

[creativecommons.org/licenses/by-sa/3.0/deed.en]

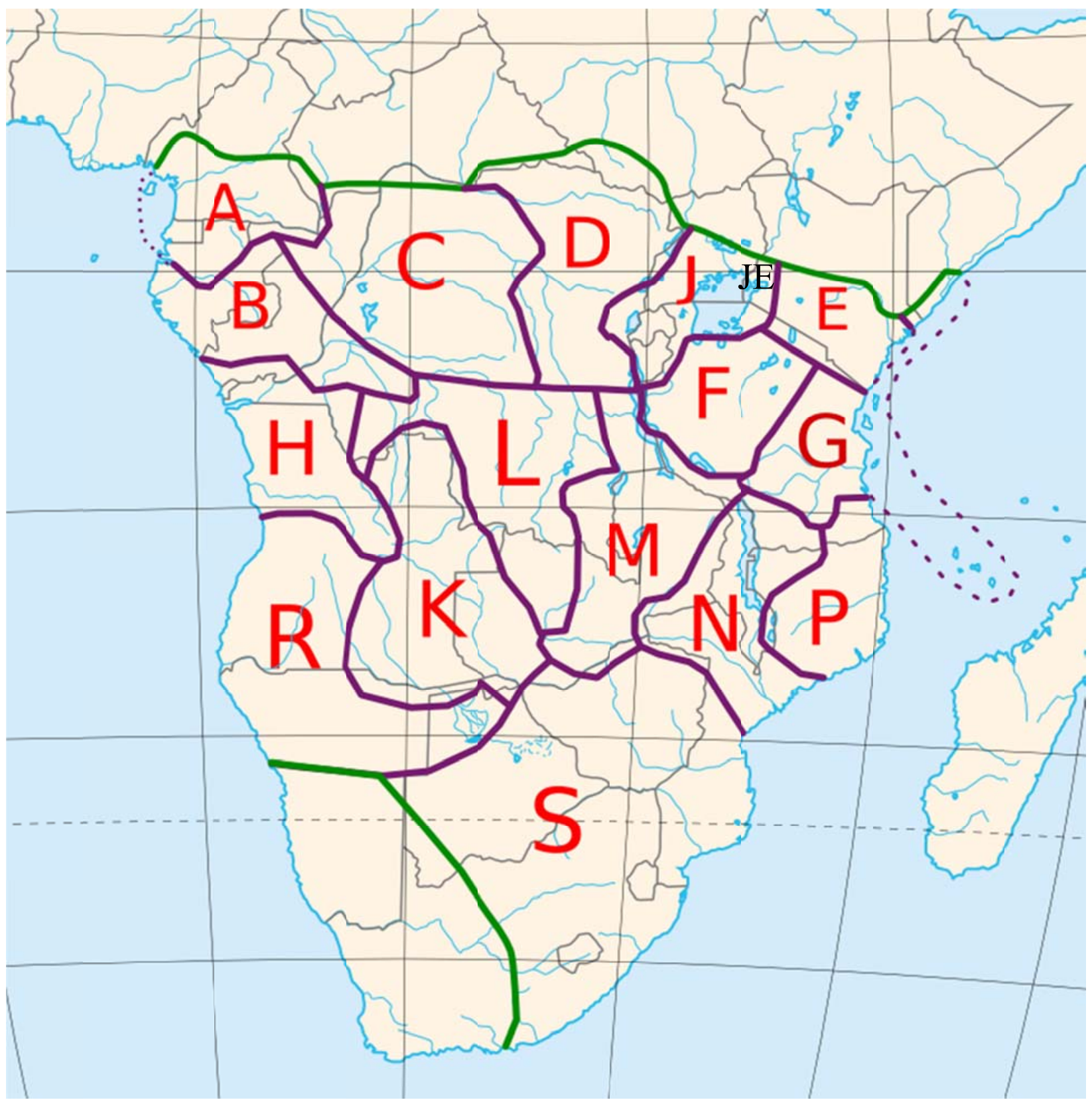

